\title{
Profil Kadar Hemoglobin Dan Indeks Eritrosit PADA Penjual Ikan Bakar Di Kota Palangkaraya
}

\author{
${ }^{1 *}$ Fera Sartika, ${ }^{2}$ Dwi Purbayanti, ${ }^{3}$ Eny Lestari
}

1) Dosen Program Studi D-III Analis Kesehatan FakultasI Imu Kesehatan, UniversitasMuhammadiyahPalangkaraya

2) Mahasiswa Program Studi D-III Analis Kesehatan Fakultas IImu Kesehatan, UniversitasMuhammadiyahPalangkaraya e-mail : sartikafera3@gmail.com

\begin{abstract}
ABSTRAK
Proses ikan dengan cara dipanggang atau dibakar dengan menggunakan arang dapat menghasilkan senyawa kimia toksik, salah satunya adalah senyawa karbon monoksida (CO). Senyawa CO dapat terhirup masuk keparu-paru melalui system pernafasan pada manusia, sehingga menggantikan posisi oksigen untuk berikatan dengan hemoglobin dan akibatnya kadar oksigen dalam darah menjadi berkurang. Tujuan penelitian ini adalah untuk mengetahui profilkadar hemoglobin dan index eritrosit penjual ikan bakar yang berjualan di sekitar Kecamatan Pahandut Kota Palangka Raya. Penelitian dilakukan dengan teknik purposive sampling dan Jumlah sampel dalam penelitian ini sebanyak 25 orang. Hasil penelitian menunjukkan kadar haemoglobin normal sebanyak 24 orang dan dibawah nilai normal sebanyak 1 orang. Nilai MCV normal sebanyak 16 orang ,MCV dibawah nilai normal sebanyak 9 orang (36\%). $\mathrm{MCH}$ normal sebanyak 21 Orang (84\%), $\mathrm{MCH}$ dibawah nilai normalsebanyak 2 orang $(8 \%), \mathrm{MCHC}$ normal sebanyak 19 orang $(68 \%), \mathrm{MCHC}$ dibawah nilai normal sebanyak 1 orang (1\%), MCHC lebih dari nilai normal sebanyak 5 orang $(20 \%)$. Profil $\mathrm{Hb}$ dan index eritrosit dari 25 sampel didapatkan kadar hemoglobin yang normal sebanyak 24 orang (96\%) dan kadar haemoglobin dibawah nilai normal normal sebanyak 1 orang (4\%). Hasil indek seritrosit sebanyak 1 orang (4\%) diduga mengalami anemia mikrositikhipokrom yang bias disebabkan oleh defisiensi besi, dan 1 orang (4\%) berjenis diduga mengalami anemia mikrositikhipokrom.
\end{abstract}

Kata kunci: Kadar Hemoglobin, Index eritrosit, Penjual Ikan Bakar 


\begin{abstract}
ABSTRACK
The process of fish by baking or burning using charcoal can produce toxic chemical compounds, one of which is a carbon monoxide $(\mathrm{CO})$ compound. $\mathrm{CO}$ compounds can be inhaled into the lungs through the respiratory system in humans, thereby replacing the position of oxygen to bind to hemoglobin and consequently the level of oxygen in the blood becomes reduced. The purpose of this study was to determine the profile of hemoglobin and erythrocyte indices of grilled fish seller selling around Pahandut District, Palangka Raya City. The study was conducted with a purposive sampling technique and the number of samples in this study were 25 people. The results showed normal hemoglobin levels of 24 people and below the normal value of 1 person. Normal MCV values were 16 people, MCV below normal values were 9 people $(36 \%)$. Normal MCH 21 people $(84 \%), \mathrm{MCH}$ under normal values 2 people (8\%), normal MCHC 19 people (68\%), MCHC below normal values 1 person (1\%), MCHC more than normal values 5 people (20\%).

Conclusion: Profile and erythrocyte indices of 25 samples obtained normal hemoglobin levels of 24 people (96\%) and hemoglobin levels below normal values of 1 person (4\%). The results of 1 person (4\%) cytitrocyte index were suspected of having microcytic hypochromic anemia which could be caused by iron deficiency, and 1 person (4\%) of the type was suspected of having microcytichipchromic anemia.
\end{abstract}

Keywords: Hemoglobin Levels, Erythrocyte Index, Grilled Fish Seller

\section{PENDAHULUAN}

Ikan bakar merupakan suatu makanan yang khas di Indonesia, khususnya kota palangkaraya. Makanan ini sering disajikan disetiap warung atau restoran yang ada di kota palangkaraya. Pengolahan ikan bakar dilakukan dengan cara di panggang diatas arang atau bara api.

Menurut World Health Organization (WHO) Ikan yang diproses dengan cara dipanggang atau dibakar dengan menggunakan arang dapat menghasilkan senyawa kimia toksik yang dapat memberikan pengaruh bagi kesehatan dalam jangka pendek ataupun jangka panjang seperti karbon monoksida (CO), partikulat (PM), polisiklik aromatik hidrokarbon (PAH), nitrogen oksida (NOx), sulfur dioksida $\left(\mathrm{SO}_{2}\right)$, senyawa organik mudah menguap (VOC), logam berat (flouraide, arsenik, timbal, merkuridan selenium) dan [1].

Senyawa kimia atau gas yang ada diudara seperti oksigen, nitrogen, karbon monoksida, dan gas lainnya dapat terhirup masuk keparu-paru melalui system pernafasan pada manusia. Gas tersebut masuk keparu-paru mengalir ke alveoli dan masuk ke aliran darah [2] 
Senyawa kimia CO memiliki daya ikat yang besar jika dibandingkan daya ikatnya terhadap oksigen. $\mathrm{CO}$ masuk kedalam tubuh manusia melalui system pernafasan kemudian masuk kealiran darah, tedifusi melalui membran alveolar bersama dengan oksigen, setelah larut dalam darah $\mathrm{CO}$ berikatan dengan hemoglobin membentuk COHb. Ikatan antara $\mathrm{CO}$ dan $\mathrm{Hb}$ terjadi dalam kecepatan yang sama antara ikatan $\mathrm{O} 2$ dan CO, tetapi ikatan untuk CO 245 kali lebih kuat daripada $\mathrm{O}_{2}$. Oleh karena itu, gas CO sangat berbahaya karena dapat menggantikan posisi oksigen untuk berikatan dengan hemoglobin dan akibanya kadar oksigen dalam darah menjadi berkurang [2], [3].

Kadar hemoglobin sering digunakan untuk menyatakan derajat anemia dan untuk mengklasifikasikan derajat anemia maka dapat dilakukan pemeriksaan indek seritrosit yang terdiri dari Mean Corpuscular Volume (MCV), Mean Corpuscular Hemoglobin (MCH), dan Mean Corpuscular, Hemoglobin Concentration (MCHC) [4].

Hemoglobin darah secara normal berfungsi dalam sistem transport, berperan membawa oksigen dalam membentuk oksihemoglobin $\left(\mathrm{O}_{2} \mathrm{Hb}\right)$ dari paru-paru ke sel-sel tubuh dan membawa gas $\mathrm{CO}_{2}$ dalam bentuk $\mathrm{CO}_{2} \mathrm{Hb}$ dari sel-sel tubuh ke paru-paru. Adanya $\mathrm{COHb}$ mengakibatkan suplai oksigen dalam jaringan menjadi berkurang, sehingga jaringan dan sel-sel tubuh mengalami kekurangan oksigen atau terjadi hipoksia. Hal tersebut dikarenakan kemampuan darah untuk transpor oksigen ke jaringan tubuh menjadi berkurang. Sehingga penting untuk diketahui konsentrasi $\mathrm{COHb}$ dalam darah, karena semakin tinggi konsentrasi $\mathrm{COHb}$ dalam darah maka semakin berpengaruh terhadap kesehatan [2]

\section{METODOLOGI}

Jenis penelitian yang digunakan adalah deskriptif yaitu suatu metode penelitian yang dilakukan dengan tujuan untuk mendeskripsikan atau menggambarkan suatu fenomena yang terjadi di dalam masyarakat atau kelompok. Populasi dalam penelitian ini adalah penjual ikan bakar yang berjualandi sekitarKecamatan Pahandut Kota Palangka Raya. Pengambilan sampel dilakukan dengan teknik purposive sampling, kemudian sampel dianalisis di laboratorium.Jumlah sampel dalam penelitian ini sebanyak 25 orang.

\section{HASIL DAN PEMBAHASAN}

Berdasarkan jenis kelamin, responden paling banyak yang berjenis kelamin laki-laki, dibandingkan perempuan yaitu sebanyak 23 orang dari total jumlahr esponden yaitu sebanyak 25 orang. 
Tabel 1. Karakteristik Subjek

\begin{tabular}{lc}
\multicolumn{1}{c}{ Parameter } & $\begin{array}{c}\text { Subjek (rerata) } \\
(\mathrm{n}=25)\end{array}$ \\
\hline Jeniskelamin & $23 / 2$ \\
Umur & 29 (Tahun) \\
Lama Berjualan & 4,5 (tahun)
\end{tabular}

Karakteristik subjek pada tabel 1, responden sebanyak 23 orang laki-laki umur 29 tahun, dan rerata lama dan 2 orang perempuan dengan rerata berjualan makanan di panggang adalah 4,5 tahun.

Tabel 1. HasilPemeriksaan Kadar Hemoglobin dan Index Eritrosit Berdasarkan Jenis Kelamin

\begin{tabular}{|c|c|c|}
\hline \multirow{2}{*}{$\begin{array}{c}\text { Hbdan Index } \\
\text { Eritrosit }\end{array}$} & \multicolumn{2}{|c|}{ Terpapar (rerata) } \\
\hline & Laki-laki & Perempuan \\
\hline $\mathrm{Hb}$ & $15,3 \mathrm{~g} / \mathrm{dl}$ & $13,6 \mathrm{~g} / \mathrm{dl}$ \\
\hline MCV & $80,6(\mathrm{fl})$ & $82,6(\mathrm{fl})$ \\
\hline $\mathrm{MCH}$ & $28,6(p g)$ & $28,7(p g)$ \\
\hline $\mathrm{MCHC}$ & 35,4 (g/dl) & 34,7 (g/dl) \\
\hline
\end{tabular}

jenis kelamin prie dan wanita masih dalam Hasil kadar hemoglobin pada batas normal. Hal ini diduga bahwa penjual ikan bakar di wilayah Kecamatan paparan senyawa kimia dari proses Pahandut Kota Palangka Raya, berdasar pembakaran ikan bakar tersebut tidak kan jenis kelamin, didapatkan reratakadar secara langsung terhirup kesaluran hemoglobin pada laki-laki adalah 15,3 pernafasan penjual., dimana dari hasil $\mathrm{g} / \mathrm{dl}$, nilai MCV 80,6 fl, nilai $\mathrm{MCH} 28,6 \mathrm{pg}$, wawancara dan observasi responden dan nilai $\mathrm{MCHC} 35,4 \mathrm{~g} / \mathrm{dl}$, sedangkan rata-rata menggunakan kipas angin pada pada jenis kelamin perempuan didapatkan saat proses pembakaran dan kipas angin rerata kadar hemoglobin adalah13,6 $\mathrm{g} / \mathrm{dl}$, Nilai MCV 82, $6 \mathrm{fl}$, nilai $\mathrm{MCH} 28,7 \mathrm{pg}$ dan tersebut tidak secara langsung mengenai penjual.

nilai $\mathrm{MCHC} 34,7 \mathrm{~g} / \mathrm{dl}$. Hasil dari penelitian ini menunjukkan bahwa kadar hemoglobin dan index eritrosit pada penjual ikan bakar 


\section{KESIMPULAN}

Profil kadar hemoglobin dan indek eritrosit pada penjual ikan bakar di Kecamatan Pahandut Kota Palangka Raya dapat disimpulkan dari 25 responden didapatkan kadar hemoglobin yang normal sebanyak 24 orang (96\%) dan kadar haemoglobin kurang dari normal sebanyak 1 orang (4\%). Hasil indek seritrosit sebanyak 1 orang (4\%) berjenis kelamin laki-laki mengalami anemia mikrositikhipokrom yang bias disebabkan oleh defisiensi besi, dan 1 orang (4\%) berjenis kelamain laki-laki dicurigai mengalami anemia mikrositikhipokrom walaupun kadar haemoglobin masih dalam rentang nilai normal.

\section{DAFTAR PUSTAKA}

1. WHO. 2010. "Selected Pollutants." WHO Guidelines for Indoor Air Quality: Selected Pollutants, 484. doi:10.1186/2041-1480-2-S2-I1.

2. Dewanti, I.R. 2018. Identification of $\mathrm{CO}$ Exposure, Habits, $\mathrm{COHb}$ Blood and Worker's Health Complaints on Basement Waterplace Apartment, Surabaya.

3. Suyono. 2014. "PencemaranKesehatanLingkungan" Jakarta: EGC

4. JurnalKesehatanLingkungan. 10 (1): 59-69
5. JadhavSaili $U$ and KhapardeSadhana. 2017. Study of the red cell indices, hemogram and platelet variations in anaemic $(<10 \mathrm{gm} \%)$ patients by automatic cell counter in a tertiary care centre, Ahmednagar, Maharashtra, India. Int $J$ Res Med Sci. 5(4):1582-1588

6. Masrizal. 2007. AnemiaDefisiensiBesi. JurnalKesehatanMasyarakat. 2(1) 